\title{
DEBT MANAGEMENT IN BRAZIL: EVALUATION OF THE REAL PLAN AND CHALLENGES AHEAD
}

\author{
AFONSO S. BEVILAQUA and MÁRCIO G.P. GARCIA* \\ Pontifical Catholic University of Rio de Janeiro (PUC-Rio), Brazil
}

\begin{abstract}
The Brazilian domestic debt has posed two challenges to policy-makers: it has grown very fast and its maturity is extremely short. This has prompted fears that a default or a compulsory lengthening scheme would be imposed. Here, we analyse the domestic public debt management experience in Brazil, searching for policy prescriptions for the next few years. After briefly reviewing the recent domestic public debt history, we decompose the large rise in federal bonded debt during 1995-2000, searching for its macroeconomic causes. The main culprits are the extremely high interest payments - which, until 1998, were caused by the weak fiscal stance and the quasi-fixed exchange-rate regime; and since 1999 , by the impact of the currency depreciation on the dollar-indexed and the external debt-, and the accumulation of assets of doubtful value, much of which may have to be written off in the future. Simulation exercises of the net debt path for the near future underscore the importance of a tighter fiscal stance to prevent the debt-GDP ratio from growing further. Given the need to quickly lengthen the debt maturity, our main policy advice is to foster, and rely more on, inflation-linked bonds. Copyright (C) 2002 John Wiley \& Sons, Ltd.
\end{abstract}

JEL CODE: E65; H63

KEY WORDS: public debt; debt structure; debt management; Brazil

\section{EXECUTIVE SUMMARY}

During the 1995-2000 period, the net public debt of the consolidated public sector in Brazil increased from 30.38 to $46 \%$ of GDP. This dramatic growth has raised many doubts about the sustainability of the current economic policy in the country. These concerns have been further increased by the exchange rate devaluation of January 1999, which raised even more the stock of the domestic public debt-due to the existence of dollar-linked indexation clauses on part of the debt-, as well as the stock (in R\$) of the foreign debt. The concerns about sustainability have been compounded by those related to the very short maturity of the domestic public debt, which increased the vulnerability of the country.

In this paper we assess the experience with public debt management in Brazil in recent years, attempting to evaluate its main lessons and derive policy guidelines for the next few years, with emphasis on the issues pertaining to the structure of the debt (denomination, indexation and maturity). We review in Section 2 the genesis of the modern domestic public debt market in Brazil. After being conceived in the second half of the 1960s as a non-inflationary instrument of public finance, and based, initially, entirely on inflation-linked bonds, the public debt market expanded substantially in its early years, generating for a while a seemingly costless way to fund public expenditures. During the 1980s, with the rise in inflation, cash management activities became predominant in the debt market. Since then, the maturity of the public debt has been remarkably short. With the inflation stabilization provided by the Real plan (July, 1994), the debt has been gradually lengthened while nominal bonds became more prevalent, even when total debt was growing fast due to fiscal deficits. The international financial crises since 1997 changed that trend in the debt structure.

*Correspondence to: Department of Economics, Pontifical Catholic University of Rio de Janeiro (PUC-Rio), Brazil.

E-mail: marcio@econ.puc.rio.br;asb@econ.puc.no.br

Copyright (C) 2002 John Wiley \& Sons, Ltd. 
As of December 2000, the share of nominal bonds was only $15.34 \%$, while the average remaining life of the debt is still very short.

Section 3 decomposes the large rise in federal bonded debt during 1995-2000, searching for its macroeconomic causes. It attempts to quantify the contraction and expansion sources of the rapid increase in the stock of federal bonded debt that occurred during the period. The main culprits are the weak fiscal stance, and the very high interest rates and the accumulation of assets of doubtful value. In Section 4 we perform simulation exercises of the public net debt path until 2012. We show that even under favourable macroeconomic conditions the evolution of the public net debt to GDP ratio will remain a policy concern in coming years. Policy conclusions are summarized in Section 5, where we discuss the role of public debt management in Brazil in the near future. Our main policy advice is that the rollover of the domestic public debt should be made with inflation-indexed bonds, in order to lengthen the maturity without creating timeconsistency problems. We add a few suggestions on how this shift could be accomplished.

\section{INTRODUCTION}

From 1995 through 2000, the net public debt of the consolidated public sector in Brazil increased from $30.28 \%$ to $46 \%$ of GDP. This dramatic growth has raised many doubts about the sustainability of the current economic policy in the country. These concerns have been further increased by the exchange rate devaluation of January 1999, which raised even more the stock in domestic currency (R\$) of the domestic public debt, due to the existence of dollar-linked indexation clauses on part of the debt, as well as the stock of the foreign debt. The concerns about sustainability have been compounded by those related to the very short maturity of the domestic public debt.

In this paper we assess experience with public debt management in Brazil in recent years, attempting to evaluate its main lessons and derive policy guidelines for the next few years, emphasizing the issues related to the structure of the debt. Section 2 discusses the evolution of the domestic bonded public debt since 1970, with an emphasis on volume and composition (indexation and maturity) during the Real Plan. Section 3 decomposes the large growth observed in the federal bonded debt during 1995-2000, searching for its macroeconomic causes. It attempts to quantify the contraction and expansion sources of the rapid increase in the stock of federal bonded debt that occurred during the period. In Section 4, we simulate paths of the net public debt until 2012. We show that even under favourable macroeconomic conditions the evolution of the public net debt to GDP ratio will remain a policy concern in coming years. With the previous sections as background, Section 5 concludes the paper with a policy analysis of public debt management in Brazil in the near future. Our main policy advice is that the rollover of the domestic public debt should employ inflation-indexed bonds, in order to lengthen the maturity without creating time-consistency problems.

\section{DOMESTIC BONDED DEBT ${ }^{1}$}

\subsection{Historical Background (1970-1994)}

The beginning of the existing market for domestic public debt in Brazil was the financial reforms introduced by the military government in the second half of the $1960 \mathrm{~s}$. Those reforms envisaged three big measures to solve the inflationary problem of the previous ten years (inflation rose from $15 \%$ to $80 \%$ a year between 1955 and 1964): the creation of marketable public securities to finance fiscal deficits; the creation of the Central Bank; and the adoption of a banking system with a clear-cut separation between commercial banks and non-bank institutions.

Figure 1 displays the evolution of the total federal government debt, separating the Central Bank holdings of government debt from the outstanding debt held by the private sector. During the high inflation years - from the early 1980s to the mid-1990s-there had been a widening of the fraction of the public debt 


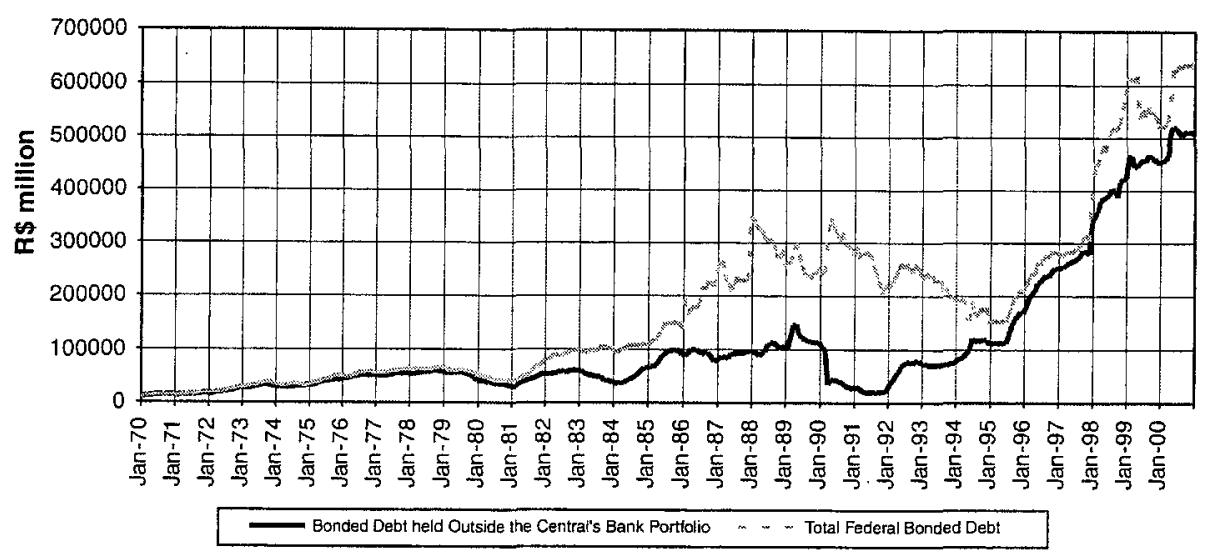

Figure 1. Federal bonds: 1970-2000.

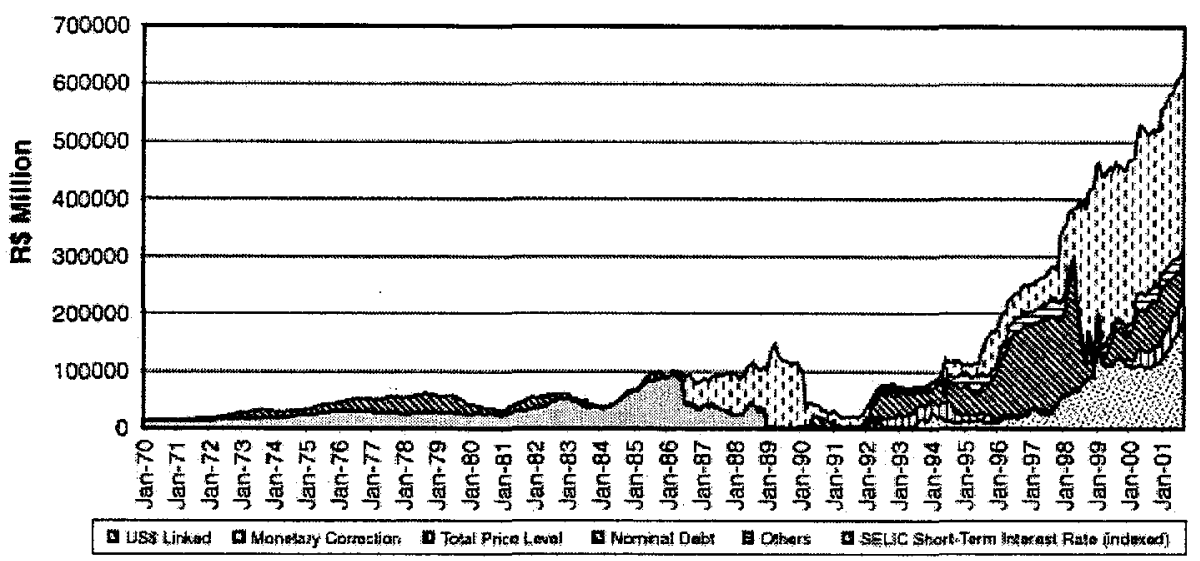

Figure 2. Federal bonded debt structure: 1970-2000.

held by the Central Bank. Under high inflation, cash management activities tended to predominate in the banking sector and the Central Bank backing of such activities required the automatic provision of liquidity to banks' holdings of public debt. This situation stood in marked contrast to the stated objectives of the reforms. Nevertheless, the objective of institutional development of a market for government debt, which had been stated in the financial reforms of 1964-1965, had been attained.

The domestic public debt market in Brazil started with indexed bonds in the late 1960s. Only in August 1970 , nominal bonds were placed (for the stated purpose of conducting monetary policy). ${ }^{2}$ Indexed bonds (ORTNs-Obrigaçōes Reajustáveis do Tesouro Nacional) were seen by asset holders as a hedge against inflation-induced erosion of financial wealth despite the fact that, until 1974, monetary correction was arbitrarily defined each month by an act of the Ministry of Finance, without official commitment to any particular price index.

Without indexed bonds, the financial markets would not have developed as they did in the face of the accelerating annual inflation rates from 1973 to 1994 . Figure 2 displays the remarkably mobile structure of the Brazilian domestic public debt.

During the infancy of the public domestic debt market (1966-1971), the demand for public debt grew ahead of the government's financial needs. A large stock of public domestic debt was deemed convenient for regulating short-run liquidity of the banking system, by means of final sales and purchases of public 


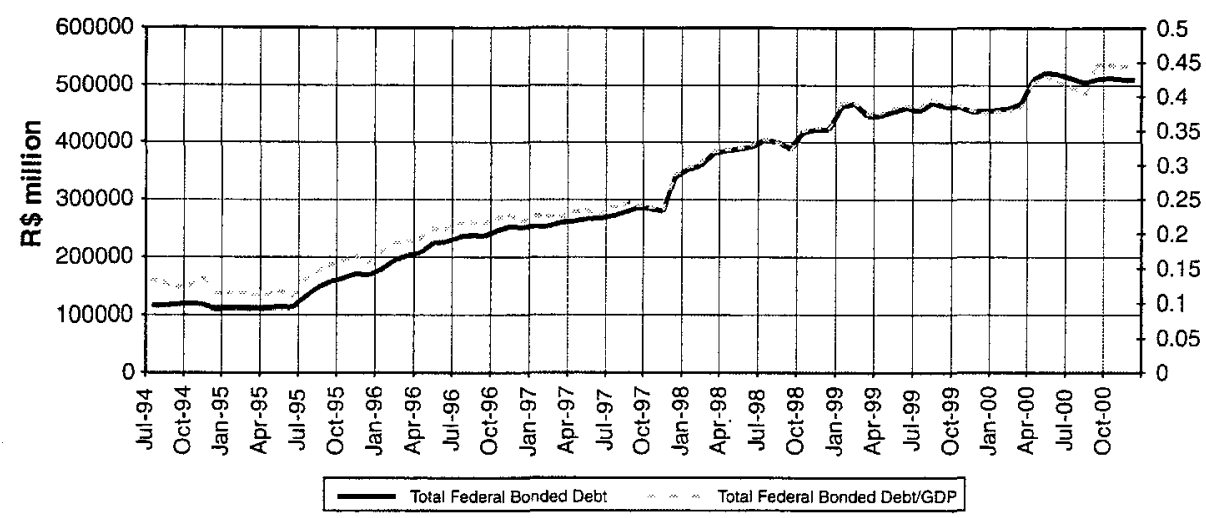

Figure 3. Federal bonded debt held Outside the CB's portfolio: the Real Plan.

debt in the open market. As in 'Say's law', however, the possibility of creating a large debt supply opened room for the creation, in the Central Bank, of a wide range of credit programs designed to fund agricultural projects and regional development, and has fostered the establishment of regional development banks at the state level. The excess demand for public bonds in the early years of the market led the Central Bank to assume the role of a financing agent, ${ }^{3}$ an aberration that lasted for years. The development strategy of the 1970s was based in great measure on the public sector's ability to issue debt to fund development projects.

By the late 1970s and early 1980s, it became clear that this growth engine had stalled. The decade witnessed high and unstable inflation, which led to a considerable increase in the volatility of the expected returns on government debt due both to a decline in the use of public savings and to frequent changes in monetary correction rules (i.e. partial disguised defaults). The 1980 s are called the lost decade, due to the economic stagnation, the megainflation, and the decline in public, as well as private, investment. As a consequence, the accumulation of public debt seemed to be approaching the end, and, by the turn of the decade, a default on domestic public debt was seen by many as an unavoidable outcome.

In fact, the new government who took office in 1990 decreed the blocking of $80 \%$ of all financial assets. The terms of the decree were actually complied with, and the government was able to unblock all the financial assets beginning 17 months later, in 12 monthly instalments. During 1993-1994, capital inflows added to demand for high-yield public debt, creating a more stable environment that made the Real Plan possible.

\subsection{Recent evolution: The Real Plan}

In July 1994, a new currency, the Real, was introduced, as the last part of the de-indexation program. Both the debt structure and size changed in important ways after the monetary reform, as the annual inflation rate fell from a four-digit figure to a one-digit figure. Until the Asian crisis (October, 1997), foreign capital kept flowing in steadily, and the domestic public debt market experienced a period of gradual maturity lengthening due to decreasing yield volatilities. After the last quarter of 1997, a series of ups and downs has characterized the international finance scene for the emerging markets, also affecting the domestic public debt market. After a semester when more than US $\$ 45$ billion of foreign reserves vanished, the Brazilian government decided to float the Real in January 1999, thereby inaugurating a new phase of the Plan. We analyse below the debt accumulation process since the introduction of the new currency, the Real, emphasizing debt size and structure (indexation and maturity).

2.2.1. Size. The extremely fast increase of the federal bonded debt during the Real Plan was one of the macroeconomic indicators. Figure 3 displays the evolution of the federal bonded debt in constant $R \$$ of December 2000, and as percent of GDP. It is quite clear that, after remaining stable during the first year of the new currency (July 1994 to June 1995), both measures of debt accumulation started trending upward. 


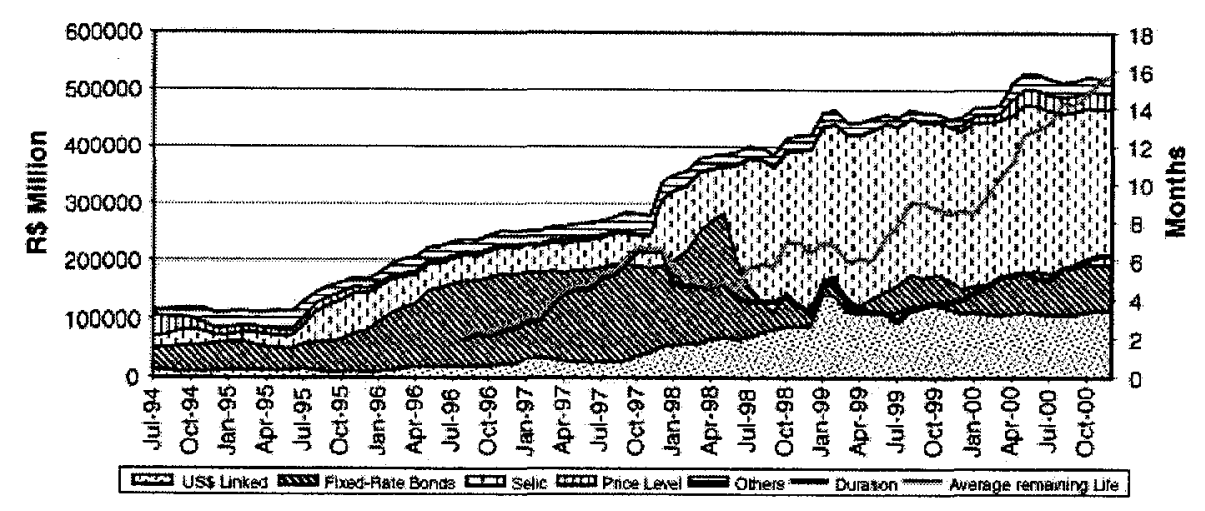

Figure 4. Federal bonded debt: composition and average maturity.

In nominal terms, the federal bonded debt increased by eight times in six years! Section 3 identifies the factors responsible for this enormous growth.

2.2.2. Composition. This section analyses the structure of the domestic debt, i.e. its composition: denomination of the debt (domestic currency versus foreign currency), indexation (to domestic price levels, to the exchange rate, to short-term interest rates, etc.), and maturity structure. We also explore new measures of risk exposure, as the V@R (Value-at-Risk).

2.2.2.1. Denomination and Indexation. All domestic federal bonded debt is redeemable only in RS. Only the external debt is redeemable in foreign currency. Figure 4 displays the domestic federal debt composition after the Real Plan. It is clear that when the debt started trending upwards in mid-1995, it was the nominal (non-indexed) part that was mainly responsible for the growth. Notwithstanding the increasing share of nominal in total debt, average maturity kept lengthening. Barcinski (1997) computed a measure of risk usually applied to financial institutions portfolios, the V@R for the nominal federal debt. The V@R measures the amount of market risk of a given portfolio, i.e. the maximum expected loss of that portfolio in a given time span. ${ }^{4} \mathrm{He}$ showed that, notwithstanding the increase in the nominal debt and its maturity lengthening, the V@R of the nominal debt actually decreased for the first years of the Real Plan (he analysed the period 1994-1996). That reflected the fact that interest rate volatility was decreasing substantially, except for the first semester of 1995 , when it increased momentarily as a consequence of the Mexican crisis. This fall in interest rate volatility is displayed in Figure $5 .^{5}$

The share of nominal to total debt remained around 30-40\% between July 1994 and November 1995 , when it started to grow, reaching $60 \%$ around mid-1996. That share was maintained until the Asian crisis, in September 1997, when it started to drop. Until the Russian crisis, in May 1998, the nominal debt share was still above $50 \%$, despite the precipitous fall in average maturity. With the Russian crisis, the Treasury and the Central Bank started to issue only indexed debt (for reasons that will be analysed later), and the nominal debt share fell to $3.5 \%$ in December $1998 .^{6}$ After the nomination of the new Central Bank governor, in March 1999, this share has been increasing again.

The share of bonds indexed to the IGP-M (a widely used price index) decreased continuously during the whole period. According to Central Bank sources, that reflected a policy decision to stop issuing inflationlinked bonds, which were deemed inflationary. ${ }^{7}$ Dollar-linked bonds remained around $10 \%$ of the total debt between July 1994 and August 1995, falling then slightly to around 7\% of the total debt between September 1995 and February 1996. With the deterioration of the economic situation in Asia, it increased once again to reach $15 \%$ at the end of 1997 . That share rose throughout 1998 to around $21 \%$ at the year-end, showing that agents were (correctly) hedging against the forecasted devaluation. The devaluation of January 13, 1999, and the continuous depreciation after the currency was floated two days later, increased the value of the dollar-linked debt vis-à-vis the other bonds. The share jumped to $30 \%$ after the 


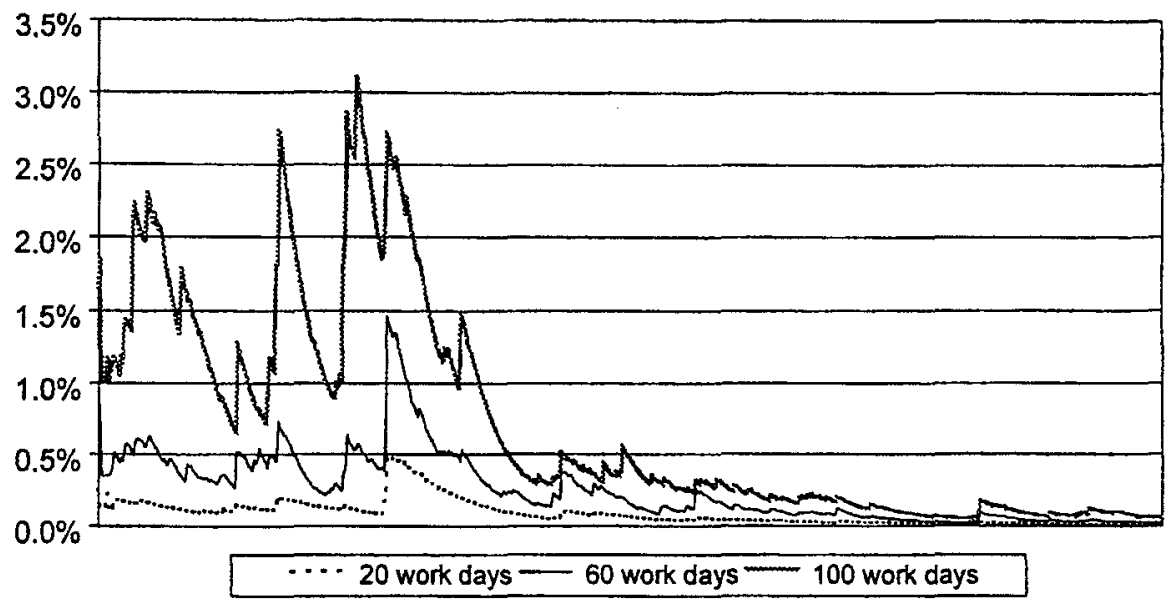

Figure 5. Daily Interest Rate Volatility: July-94 to Dec-96.

devaluation, and has fallen afterwards, as the demand for new issues of dollar-linked debt has diminished considerably and the currency appreciated after March 1999. With the new round of depreciation that started in May 1999, the demand for dollar-linked debt (or any hedge against depreciation) has been increasing again, forcing the Central Bank to supply more of this kind of debt. ${ }^{8}$

The share of bonds indexed to the short-run interest rate (or zero-duration bonds) was around $25 \%$ of the total debt between July 1994 and July 1995, 35\% between August 1995 and February 1996, falling to approximately $20 \%$ in November 1997. In December 1997, a large issue of this kind of bonds distorted all debt-statistics. Around R \$ 50 billion of bonds were issued as part of a renegotiation deal with the Brazilian state of São Paulo, ${ }^{10}$ making the share of zero-duration bonds jump to $35 \%$. After that, as those bonds were swapped with the Central Bank for shorter-maturity ones, their share fell gradually to $21 \%$ in May 1998, when the beginning of the Russian crisis made the Central Bank and the Treasury change strategies regarding the issuance of nominal bonds. As mentioned before, the issuance of nominal bonds stopped, and only zero-duration bonds started being issued. That move made the share of the latter jump from $21 \%$ in May to $42 \%$ in June. By December 1998, the zero-duration bond share was almost $70 \%$. It fell in January due to the increase in value of the dollar-linked bonds, and it continued to fall later as the issuance of nominal bonds resumed after March 1999. As of December 2000, its share was hovering around $52.36 \%$.

2.2.3. Maturity structure. Figure 4 shows the average maturity of the debt during the Real Plan. The average maturity of the total debt has substantially increased in relative terms although it remains low in absolute terms. ${ }^{11}$ It is nonetheless interesting that until the Asian crisis (September 1997), maturity kept increasing despite the increasing share (and total value) of the nominal debt. ${ }^{12}$ As noted before, until 1996, Barcinski (1997) showed that, the V@R of the nominal debt decreased despite the size increase and the maturity lengthening. In other words, investors in public debt were not incurring more price risk, despite the increase in the portfolio size and in the nominal debt maturity.

With the international financial crises, this virtuous circle came to an end. When Brazil began to suffer the contagion effect of the Asian crisis, in the form of a speculative attack during the week of October 27, 1997 , the Central Bank quickly reacted by increasing the basic interest rate, the TBC, (see footnote 13) from 20.70 to $43.41 \%$ (see Figure 5). After two weeks without public debt auctions, the rolling over continued with three-month-maturity bonds, at rates little below the TBC.

In that environment, the Treasury and the Central Bank probably did not want to issue long maturity debt. An interest rate of $43 \%$ per year (with the inflation rate well below $5 \%$ per year and an exchange-rate 


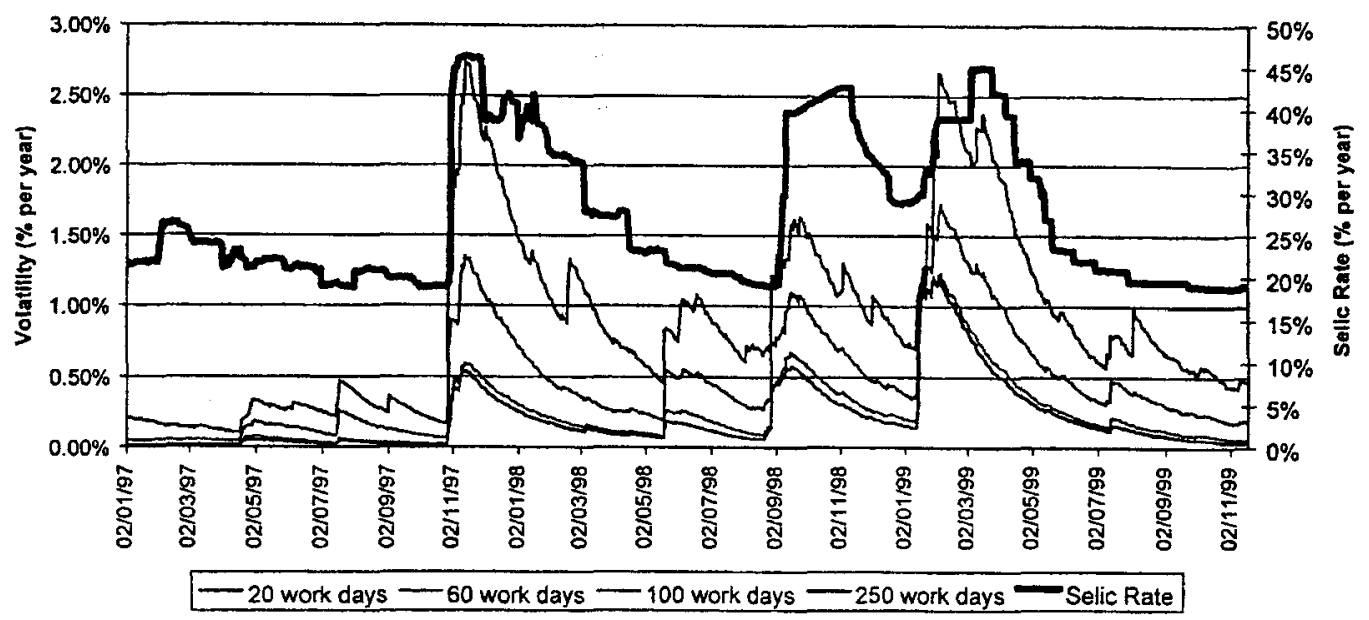

Figure 6. Level and Volatility of Interest Rate: The Crises Period.

devaluation of $7.5 \%$ per year) is clearly unsustainable in the long run, being sustainable only briefly to counteract a speculative attack. Therefore, had the Treasury and the Central Bank decided to place one or two year bonds at such a high rate, they could conceivably have sparked a panic, because of the informational content of such a move. Placing debt at $43 \%$ for short periods might be desirable, but paying such high rates for long periods puts the government budget on a clearly unsustainable path. That could then trigger expectations of a government default. In other words, in such a situation, there may be no equilibrium with such a high interest rate and long maturity. ${ }^{13}$ The only equilibrium may be the one with very short maturity bonds. An alternative explanation is that the maturity premium demanded by the market for longer maturity bonds was beyond the maximum premium implied by the auction managers' reservation prices. ${ }^{14}$ That rollover strategy had the effect of decreasing the maturity of the stock of debt. Figure 6 shows that interest rate volatilities increased tenfold during this turbulent period. As a consequence, so did the V@R measures.

Until the end of 1997, only three-month maturity bonds were placed, all with negative maturity premia. During the first five months of 1998, the Treasury and the Central Bank were able to place nominal debt with increasing maturity. However, when the Russian crisis first hit in May 1998, even short-term bonds (three or six months) became extremely costly for the issuers, as yields rose substantially. As a consequence, the market for three-month, six-month and one-year bonds vanished, and the only nominal bonds placed in the auctions after mid-May were one-month BBCs. ${ }^{15}$ In June and July, even that became too expensive, and the Central Bank resorted to its last resource, the zero-duration bond.

This decision had an immediate impact on the amounts that were rolled over in each auction. When the debt maturity decreases, the debt must be rolled over more often. That is exactly what was happening until May 1998. The amounts of monthly redeemed and issued debt tripled! This, of course, created a new source of risk - the rollover risk-i.e. that of not being able to roll over the debt in the event of a crisis, with possible impacts in the exchange-rate anchor that was in place at the time. After May, due to the strategy of placing only indexed bonds (mostly zero-duration and dollar-linked), average maturity resumed its upward trend, and the rollover risk decreased. However, this happened at a cost: if interest rates had to be lifted in the future, the fiscal budget would be badly hit. The same was valid regarding a devaluation. With the benefit of hindsight, we know now that both strategies caused massive losses to the fiscal budget.

Even with zero-duration debt, average maturity fell again in the last quarter of 1998, due to the contagion effect of the Russian default. After the devaluation, maturity has been increasing (see Figure 4). However, if the government were now to decide to quickly change the current debt structure in favour of nominal debt, either a fall in maturity or a substantial cost increase in debt service would be likely, as we will discuss in Section 5. 


\section{EVOLUTIAN OF THE GROSS DOMESTIC BONDED DEBT DURING THE REAL PLAN: A DECOMPOSITION EXERCISE}

Puring the first six years of President Fernando Henrique Cardoso's administration, the federal bonded debt increased to more than eight times its original value: from $R \$ 60$ billion to $R \$ 489$ billion (see footnote 12). This spectacular debt growth raises many doubts about the sustainability of economic policy, especially if one considers the effects of the exchange-rate devaluation in January 1999 , which increased even further the service costs of federal bonded debt, due to the existence of dollar-linked indexation clauses on part of the debt.

This section decomposes the federal bonded debt growth, searching for the macroeconomic causes of the considerable growth that occurred in the 1995-2000 period. We attempt to quantify the contraction and expansion sources of the federal bonded debt.

Consider the federal government and Central Bank aggregate balance sheets on 31 December 1994 and 31 December 2000, respectively. One of the accounts on the liability side is the federal bonded debt. The value we are interested in explaining is the difference between this account's balances on these two dates. Due to accounting identities, this value is the sum (with opposite sign) of the differences during the period of all the other accounts' balances. Consequently, by aggregating these other accounts' balances in a way amenable to our macroeconomic analysis, we measure the factors responsible for the growth of the federal bonded debt in this four-year period. The idea of this decomposition exercise can be better understood with the accounting framework provided in Table 1. The table starts from the government budget constraint, and develops an accounting identity (Equation (6)) that is suitable for our purpose of identifying the sources of the growth of the federal bonded debt.

Thus, we search for an explanation for the $R \$ 428955$ variation, as shown in Table 2, of the federal bonded debt (federal government + Central Bank).

Initially, we will aggregate the other accounts in the federal government and Central Bank aggregate balance sheet into three groups, each one of them standing for one of the following reasons to issue federal bonded debt, ${ }^{16}$ as laid out in Table 1 .

(1) To finance the federal government's (+Central Bank's) deficit

(2) To accumulate foreign and domestic assets; and

(3) To repay other previous debts (non-bonded debt).

Table 1. Debt uses: a decomposition

(1) Net debt $=$ Liabilities-assets

(2) $\Delta$ (Net debt) $=\Delta$ (Liabilities) $-\Delta$ (assets)

(3) $\Delta$ (Net debt) $=$ Primary deficit + interest payments + adjustments

(4) $\Delta$ (Liabilities $)=\Delta$ (domestic bonds $)+\Delta$ (other domestic debt $)+\Delta$ (foreign debt)

(5) $\Delta$ (Assets) $=\Delta$ (domestic assets) $+\Delta$ (foreign assets)

(3), (4), (5) $\Rightarrow(2)$, and solving for $\Delta$ (Domestic bonds)

Source of funds $=$ Uses of funds

(6) $\Delta$ (Domestic bonds) $=$ Primary deficit + interest payments + Adjustments $+\Delta$ (domestic assets $)+\Delta($ foreign assets $)-$ $\Delta$ (other domestic debt) $-\Delta$ (foreign debt)

Table 2. Federal bonded debt growth: 1995-2000

\begin{tabular}{lcccc}
\hline & December 1994 & December 2000 & Variation & Percentage variation \\
\hline Federal bonded debt (R\$) & 60255 & 489210 & $\mathbf{4 2 8 9 5 5}$ & 712 \\
GDP (R\$) & 504162 & 1142473 & 638312 & 127 \\
Federal bonded debt (\% GDP) & 11.95 & 42.82 & 30.87 & 258 \\
\hline
\end{tabular}


Table 3. Federal bonded debt uses: 1995-2000

\begin{tabular}{lcccc}
\hline & \multicolumn{2}{c}{ Table 3. Federal bonded debt uses: 1995-2000 } \\
\hline In RS (million) & December 1994 & December 2000 & Variation & Percentage variation \\
\hline Nat dobt (increase = deficit) & 65836 & 352967 & 287131 & 436.1 \\
Asset accumulation & 106559 & 376881 & 270323 & 253.7 \\
Other debts' repayments (-) & 112140 & 240639 & 128499 & 114.6 \\
Total & & & $\mathbf{4 2 8 9 5 5}$ & \\
\hline
\end{tabular}

In percent of GDP, the data above are:

Table 4. Federal bonded debt uses in percent of GDP: 1995-2000

\begin{tabular}{lllc}
\hline In percent GDP & December 1994 & December 2000 & Percentage \\
\hline Net debt (increase = deficit) & $13.06 \%$ & $30.89 \%$ & 17.84 \\
Asset accumulation & $21.14 \%$ & $32.99 \%$ & 11.85 \\
Other debt repayments (-) & $22.24 \%$ & $21.06 \%$ & -1.18 \\
& & & 30.87 \\
\hline
\end{tabular}

Item 1 represents the difference in the two net worth figures (a fiscal deficit is a loss, and a fiscal surplus is a profit); item 2, the asset accumulation during the period; and the item 3, the decrease in the aggregate of all other liability accounts. Thus, considering the federal bonded debt as the 'sources', and the other accounts as the 'uses' we can observe these uses in Tables 3 and 4, expressed in R\$ and percentage of GDP, respectively. ${ }^{17}$

Table 3 shows the federal bonded debt variation. The greatest share $(66.94 \%)$ of the increases in federal bonded debt was due to the federal deficit (which would be equal to the net debt variation, if it were not for accounting details discussed above). The accumulation of assets was responsible for a little bit less, $63.02 \%$ of the federal bonded debt growth. The increase in other debts was responsible for the (negative) residual factor $(29.96 \%)$, which means that if the other debts had not grown by $R \$ 128499$, the federal bonded debt would have increased even more. Measured as a share of GDP, the federal deficit was responsible for $57.78 \%$ of federal bonded debt growth of $30.87 \%$ of GDP (Table 4). The accumulation of assets was responsible for $38.40 \%$ of the federal bonded debt growth, while the other debts actually decreased as a percent of GDP, being responsible for the remaining $3.82 \%$ of the federal bonded debt growth. ${ }^{18}$

We now turn to the decomposition of each of these three factors: the federal deficit, the assets accumulation, and the repayment of other debts.

\subsection{Financing of the Federal Government ( + Central Bank) Deficit}

In order to make the net debt variation of the period (R $\$ 287131$ or $17.84 \%$ of the GDP) compatible with the nominal deficits registered during the same period, it is necessary to make three adjustments. The first is to add the states', municipalities' and state-owned enterprises' net debt variation.

The second adjustment recognizes the privatization revenues. Since privatization revenues occur only once; they are not included in the public deficit computation. Nevertheless, they are public revenues which, ceteris paribus, would lower the net debt (the state-owned enterprises that were sold were not previously included in the public sector assets). Keeping the hypothesis that everything else stayed constant, and assuming that all the privatization revenues were used for public debt redemption, the gross debt would diminish by the exact amount of these privatization revenues. Therefore, we have to add these revenues to the variation of the total net debt in order to obtain the debt variation concept that best conforms to the public deficit statistics. ${ }^{19}$ 
The third adjustment is related to the 'Balance Sheet Adjustment. ${ }^{20}$ The idea of this adjustment is that the macroeconomic impacts of the 'skeletons' (old debts that were eventually repaid) occurred in the past. For example, the public debt issue for Banco do Brasil's recapitalization-whose accumulated losses were threatening its solvency-recognized losses derived from bad credit expansions in the past. Indeed, the debt issue was not related to deficits during the recapitalization period, but to old deficits, that had never been recognized until then. Thus, it is necessary to subtract the Balance Sheet adjustment's variation from the total net debt to obtain the debt variation concept comparable to the public deficit, namely, the 'Net Fiscal Debt without Privatization'.

Therefore, the following accounting identity should hold: for the fiscal statistics published by the Brazilian Central Bank.

Increase in net fiscal debt without privatization $=$ nominal deficit Making the adjustments, we obtain

Table 5. Making compatible the net federal debt statistics and the nominal debt statistics in R\$: 1995-2000

\begin{tabular}{lrrrc}
\hline In R\$ (million) & Dec/94 & Dec/00 & Variation & Percentage variation \\
\hline Net federal debt (+Central Bank) & 65836 & 325967 & 287131 & 436.13 \\
+ State's and municipalities' net debt & 51091 & 185323 & 134232 & 262.73 \\
+ State-owned enterprises' net debt & 36236 & 24873 & -11363 & -31.36 \\
= Total net debt & 153163 & 563163 & 410000 & 267.69 \\
- Balance sheet adjustment & 0 & 97664 & 97664 & \\
+ Privatization adjustment & 0 & 59862 & 59862 & \\
= Net fiscal debt without privatization & 153163 & 525360 & 372197 & 243.01 \\
\hline
\end{tabular}

Table 6. Making compatible the net federal debt statistics and the nominal debt statistics in percent of GDP: 1995-2000

\begin{tabular}{lrrr}
\hline In percent of GDP & Dec/94 & Dec/00 & Percentage variation \\
\hline Net federal debt (+ Central Bank) & $13.06 \%$ & $30.89 \%$ & 17.84 \\
+ State's and municipalities' net debt & $10.13 \%$ & $16.22 \%$ & 6.09 \\
+ State-owned enterprises' net debt & $7.19 \%$ & $2.18 \%$ & -5.01 \\
= Total net debt & $30.38 \%$ & $49.29 \%$ & 18.91 \\
- Balance sheet adjustment & $0.00 \%$ & $8.55 \%$ & 8.55 \\
+ Privatization adjustment & $0.00 \%$ & $5.24 \%$ & 5.24 \\
= Net fiscal debt without privatization & $30.38 \%$ & $45.98 \%$ & 15.60 \\
\hline
\end{tabular}

Table 7 shows the evolution and the composition of the public deficit during the 1995-2000. The net federal debt variation is slightly higher than the nominal deficits accumulated in the same period $(372199-363933=8264)$. This difference occurred during 1995 , when the Balance Sheet adjustments' methodology was not yet implemented. Therefore, an extra item will be included, 'Adjustment not computed by the CB', amounting to $\mathrm{R} \$ 8264$ million.

After all these adjustments, the equation which links the federal debt variation $(+\mathrm{CB}$ with the federal nominal deficit is expressed in Table 8. It shows that largest share of item 1 , which can be identified with the financing of the federal public debt $(+\mathrm{CB})$, was due to interest payments $(90.67 \%)$. Item I's second biggest expansion source was the Balance Sheet adjustment. Note that this expansion effect from the Balance Sheet adjustment $(34.01 \%)$ was substantially weakened by the privatization's contractionary effect $(-20.85 \%)$. As we have already discussed, none of these items constitutes exactly the public deficit. According to the definition of the federal deficit, neither of the other items-related to states and municipalities $(2.86 \%$ of 
Table 7. Public sector borrowing requirements: $1995-2000$

\begin{tabular}{lrrrrrrr}
\hline In RS (million) & \multicolumn{1}{c}{1995} & \multicolumn{1}{c}{1996} & \multicolumn{1}{c}{1997} & \multicolumn{1}{c}{1998} & \multicolumn{1}{c}{1999} & \multicolumn{1}{c}{2000} & Accumulated \\
\hline Nominal & 47027 & 45741 & 53232 & 72490 & 96158 & 49285 & 363933 \\
$\quad$ Federal government and CB & 15392 & 19946 & 22912 & 49361 & 66209 & 34496 & 208315 \\
$\quad$ States and municipalities & 23067 & 21076 & 26377 & 18416 & 30589 & 22291 & 142447 \\
State-owned enterprises & 8568 & 4720 & 3943 & 4713 & -640 & -8132 & 13171 \\
& & & & & & & \\
Nominal Interest & 48750 & 45001 & 44923 & 72596 & 127245 & 87442 & 425958 \\
$\quad$ Federal government and CB & 18728 & 22853 & 20537 & 54402 & 88881 & 54926 & 260328 \\
$\quad$ States and municipalities & 21915 & 16840 & 19941 & 16686 & 32694 & 28947 & 137023 \\
$\quad$ State-owned enterprises & 8108 & 5308 & 4444 & 1508 & 5670 & 3569 & 28606 \\
& & & & & & & \\
Primary & -1723 & 740 & 8310 & -106 & -31087 & -38157 & -62024 \\
$\quad$ Federal government and CB & -3336 & -2908 & 2375 & -5042 & 22672 & -20431 & -52013 \\
$\quad$ States and municipalities & 1152 & 4236 & 6436 & 1731 & -2105 & -6026 & -5423 \\
$\quad$ State-owned enterprises & 461 & -589 & -501 & 3204 & -6310 & -11700 & -15435 \\
\hline
\end{tabular}

Table 8. Making the federal net debt statistics and the federal nominal deficit compatible: 1995-2000

\begin{tabular}{lrr}
\hline & $\mathrm{R} \$$ (million) & Percentage share \\
\hline = Federal net debt variation (+CB) & 287131 & \\
+ Nominal interest (federal government $+\mathrm{CB})$ & 260328 & 90.67 \\
+ Primary deficit (federal government $+\mathrm{CB})$ & -52013 & -18.11 \\
+ Nominal deficit minus net debt Variation of the state and municipalities & 8215 & 2.86 \\
+ Nominal deficit minus net debt variation of the state-owned enterprises & 24534 & 8.54 \\
+ Patrimonial adjustment variation & 97664 & 34.01 \\
- Privatization adjustment variation & -59862 & -20.85 \\
+ Adjustment not computed by the Central Bank & 8264 & 2.88 \\
= Total & 287131 & 100.0 \\
\hline
\end{tabular}

item l's growth) and the state-owned enterprises (8.54\%)-should be included, since this item (1) refers only to the federal level. ${ }^{21}$ The federal government and Central Bank's primary deficit had a contractionist impact during this period $(-18.11 \%)$.

\subsection{Accumulation of assets}

Table 9 decomposes the accumulation of assets during this period. Note that domestic assets growth $(323.21 \%)$ was substantially greater than the foreign assets' growth $(97 \%)$. The growth rates are unequal among the domestic assets also. The states' debts renegotiation, which appears in items 1.3 and 1.4, is responsible for slightly more than half of this increase $(63.43 \%)$ ) ${ }^{22}$ The Central Bank's credits to financial institutions, which include the Proer (the private banks' bailout programme), played a minor role: $7.03 \%$.

\subsection{Repayment of other kinds of federal public debt}

As shown in Table 3, the other debts suffered, in nominal terms, a net increase. Therefore, if the other debts had remained the same, the federal public debt would have increased even more in nominal terms. Table 10 shows the other kinds of debt variation in this period. Once more, the domestic components 
Table 9. Assets accumulation in R\$: 1995-2000

\begin{tabular}{lrrrc}
\hline & Dec/94 & Dec/00 & Variation & Percentage variation \\
\hline 1. Domestic & 73806 & 312358 & 238552 & 323.21 \\
1.1. FAT & 12800 & 41022 & 28222 & 220.49 \\
1.2. CB's credits to financial institutions & 20561 & 37341 & 16780 & 81.61 \\
1.3. Federal government's credits (Law 8727/93) & 0.00 & 4755 & -3522 & \\
1.4. Debt renegotiations with the states & 0.00 & 154830 & 154830 & \\
1.5. Others & 32169 & 74409 & 42240 & 131.31 \\
2. Foreign reserves & 32752 & 64523 & 31771 & 97.00 \\
Total & & & & \\
\hline
\end{tabular}

Table 10. Other debt variations: 1995-2000

\begin{tabular}{lrrcc}
\hline & Dec/94 & Dec/00 & Variation & Percentage variation \\
\hline 1. Other domestic debt & 46947 & 90721 & 43774 & 93.24 \\
1.1. Monetary base & 17685 & 47679 & 29994 & 169.60 \\
1.2. Others & 29262 & 42042 & 13780 & 47.09 \\
2. Foreign debt & 65193 & 149918 & 84725 & 129.96 \\
Total & 112140 & 240639 & 128499 & 114.59 \\
\hline
\end{tabular}

growth was smaller than the foreign one (93.24\% versus $123.96 \%)$. Among the domestic net debt components, the greatest share is due to the Monetary Base, responsible for $23.34 \%$ of the total net debt variation.

Table 11 summarizes the discussion about the factors of expansion and contraction of the federal public debt (in nominal terms). One must keep in mind that, since we are working with nominal values over a period of four years, the values presented in this table can be misleading. ${ }^{23}$ It is observed that the most important factor for debt growth was interest payments $(60.69 \%)$, followed by the accumulation of the state's debt $(36.09 \%$ ). If we add these interest payments to the accumulation of domestic assets, the quality of which is uncertain, we can 'explain' more than $99 \%$ of the debt growth in this period. ${ }^{24}$ Therefore, it is quite reasonable to identify public debt growth with the deterioration of the fiscal position.

Table 12 summarizes the discussion about the factors of expansion and contraction of the federal public debt (in real terms). The analysis in real terms generates a few discrepancies from the previous analysis, and, of course, is the most relevant to the current economic situation. The interest rate share increased even more in real terms: interest payments $(27.07 \%$ of GDP) alone exceeded the full variation of the federal net debt $(17.84 \%$ of GDP). Foreign Reserves actually fell as a $\%$ of GDP $(0.85 \%)$, thereby making the whole Asset Accumulation much less attractive as an indicator of solvency.

A word of caution is necessary. One should not infer from the previous analysis that the bulk of the explosive growth in domestic bonded debt was due exclusively to the policy of extremely high interest rates, and that had the interest rates been lower, the bonded debt would not have exploded. Interest rates were high not only because of the Central Bank policy decisions, but mainly because the fiscal stance became increasingly lax as the first successes of the Real Plan appeared on the inflation front. ${ }^{25}$ Bevilaqua and Werneck (1998) show that the primary balance of the consolidated 
Table 11. Federal debt uses in R\$: 1995-2000 (R\$ Millions)

\begin{tabular}{|c|c|c|c|c|}
\hline & Dec-94 & Dec-00 & Variation & $\begin{array}{l}\text { Percentage } \\
\text { share }\end{array}$ \\
\hline Federal net debt $(+C B)$ & 65836 & 352967 & 287131 & 93.24 \\
\hline Nominal interests (Federal government $+\mathrm{CB}$ ) & & & 260328 & 60.69 \\
\hline Primary deficit (Federal government $+\mathrm{CB}$ ) & & & -52013 & -12.13 \\
\hline $\begin{array}{l}\text { Nominal deficit minus net debt and variation of the } \\
\text { states and municipalities }\end{array}$ & & & 8215 & 1.92 \\
\hline $\begin{array}{l}\text { Nominal deficit minus net debt variation of the } \\
\text { state-owned enterprises }\end{array}$ & & & 24534 & 5.72 \\
\hline Balance sheet adjustment variation & & & 97664 & 22.77 \\
\hline Privatization adjustment variation $(-)$ & & & 59862 & -13.96 \\
\hline Adjustment not computed by the Central Bank & & & 8264 & 1.93 \\
\hline Assets & 106559 & 376881 & 270323 & 63.02 \\
\hline 1. Domestic & 73806 & 312358 & 238522 & 55.61 \\
\hline 1.1. FAT & 12800 & 41022 & 28222 & 6.58 \\
\hline 1.2. CB's credits to the financial institutions & 20561 & 37341 & 16780 & 3.91 \\
\hline 1.3. Federal government's credits (Law $8727 / 93$ ) & 8276 & 4755 & -3522 & -0.82 \\
\hline 1.4. Debt renegotiations with the states & 0 & 54830 & 154830 & 36.09 \\
\hline 1.5. Others & 32169 & 74409 & 42240 & 9.85 \\
\hline 2. Foreign reserves & 32752 & 64523 & 31771 & 7.41 \\
\hline Other debts $(-)$ & 11240 & 240639 & -128499 & -29.96 \\
\hline 1. Domestic & 46947 & 90721 & -43774 & -10.20 \\
\hline 1.1. Monetary base & 17685 & 43042 & -29994 & -6.99 \\
\hline 1.2. Others & 29262 & 149918 & -13780 & -3.21 \\
\hline 2. Foreign & 65193 & & -84725 & -19.75 \\
\hline Total & & & 428955 & 100.00 \\
\hline
\end{tabular}

Table 12. Federal debt uses in percent of GDP: 1995-2000

\begin{tabular}{|c|c|c|c|}
\hline & Dec-94 & Dec-00 & Variation \\
\hline Federal net debt $(+C B)$ & $13.06 \%$ & $30.89 \%$ & $17.84 \%$ \\
\hline Nominal interests (federal government + CB) & & & 27.07 \\
\hline Primary deficit (federal government $+\mathrm{CB}$ ) & & & -5.09 \\
\hline Nominal deficit minus net debt variation of the states and municipalities & & & 0.91 \\
\hline Nominal deficit minus net debt variation of the state-owned enterprises & & & 2.90 \\
\hline Balance sheet adjustment variation & & & 9.91 \\
\hline Privatization adjustment variation $(-)$ & & & -6.01 \\
\hline Adjustment not computed by the Central Bank & & & 0.98 \\
\hline Assets & 21.14 & 32.99 & 11.85 \\
\hline 1. Domestic & 14.64 & 27.34 & 12.70 \\
\hline 1.1. FAT & 2.54 & 3.59 & 1.05 \\
\hline 1.2. CB's credits to the financial institutions & 4.08 & 3.27 & -0.81 \\
\hline 1.3. Federal Government's credits (Law 8727/93) & 1.64 & 0.42 & -1.23 \\
\hline 1.4. Debt Renegotiations with the states & 0.00 & 13.55 & 13.55 \\
\hline 1.5. Others & 6.38 & 6.51 & 0.13 \\
\hline 2. Foreign Reserves & 6.50 & 5.65 & -0.85 \\
\hline Other debts (-) & 22.24 & 21.06 & 1.18 \\
\hline 1. Domestic & 9.31 & 7.94 & 1.37 \\
\hline 1.1. Monetary Base & 3.51 & 4.17 & -0.67 \\
\hline 1.2. Others & 5.80 & 3.77 & 2.04 \\
\hline 2. Foreign & 12.93 & 13.12 & 0.19 \\
\hline
\end{tabular}


public sector deteriorated substantially during 1994-1998, while it improved remarkably in the following years.

\section{CHALlENGES AHEAD: DEBT EVOLUTION IN THE POST-DEVALUATION PERIOD}

In this section we perform simulations of the public net debt path to 2012. The starting point for the derivation of the model used for the debt-dynamics simulations is the standard budget constraint of the consolidated public sector, which in the case of Brazil includes the central government, states and municipalities and public enterprises:

$$
\begin{gathered}
\frac{M_{t}-M_{t-1}}{P_{t}}+\frac{B_{t}-B_{t-1}}{P_{t}}+\frac{E_{t}\left(B_{t}^{*}-B_{t-1}^{*}\right)}{P_{t}} \\
\equiv \frac{D_{t}}{P_{t}}+i_{t} \frac{B_{t-1}}{P_{t}}+i_{t}^{*} \frac{E_{t}}{P_{t}} B_{t-1}^{*}-\frac{A_{t}}{P_{t}}+\frac{H_{t}}{P_{t}}
\end{gathered}
$$

where $M$ is the monetary base, $B$ is the net domestic debt, $B^{*}$ is the foreign debt net of international reserves, $E$ is the nominal exchange rate in R\$ per US\$, $D$ is the primary deficit, $i$ is the domestic interest rate, $r$ is the foreign interest rate, $A$ denotes privatization revenues and $H$ represents hidden and contingent liabilities.

It is useful to rewrite Equation (1) in terms of flows and stocks per unit of domestic product:

$$
\begin{aligned}
& \frac{M_{t}-M_{t-1}}{P_{t} Y_{t}}+\frac{B_{t}-B_{t-1}}{P_{t} Y_{t}}+\frac{E_{t}\left(B_{t}^{*}-B_{t-1}^{*}\right)}{P_{t} Y_{t}} \\
& \equiv \frac{D_{t}}{P_{t} Y_{t}}+i_{t} \frac{B_{t-1}}{P_{t} Y_{t}}+i_{t}^{*} \frac{E_{t}}{P_{t} Y_{t}} B_{t-1}^{*}-\frac{A_{t}}{P_{t} Y_{t}}+\frac{H_{t}}{P_{t} Y_{t}}
\end{aligned}
$$

or

$$
\frac{B_{t}}{P_{t} Y_{t}}+\frac{E_{t} B_{t}^{*}}{P_{t} Y_{t}}=\frac{B_{t-1}}{P_{t} Y_{t}}\left(1+i_{t}\right)+\frac{E_{t}^{\prime}}{P_{t} Y_{t}} B_{t-1}^{*}\left(1+i_{t}^{*}\right)-\sigma_{t}+d_{t}-a_{t}+h_{t}
$$

where $\sigma, d, a$ and $h$ are, respectively, seignorage, primary deficit, privatization revenues and hidden and contingent liabilities in terms of GDP.

Equation (3) can be further rearranged as

$$
b_{t}+b_{t}^{*}=\frac{B_{t-1}}{P_{t-1} Y_{t-1}} \frac{\left(1+i_{t}\right)}{P_{t} Y_{t} / P_{t-1} Y_{t-1}}+\frac{E_{t-1}}{P_{t-1} Y_{t-1}} b_{t-1}^{*} \frac{E_{t}}{E_{t-1}} \frac{\left(1+i_{t}^{*}\right)}{P_{t} Y_{t} / P_{t-1} Y_{t-1}}-\sigma_{t}+d_{t}-a_{t}+h_{t}
$$

or

$$
b_{t}+b_{t}^{*}=b_{t-1} \frac{\left(1+i_{t}\right)}{\left(1+\pi_{t}\right)\left(1+n_{t}\right)}+b_{t-1}^{*} \frac{\left(1+i_{t}^{*}\right)\left(1+\varepsilon_{t}\right)}{\left(1+\pi_{t}\right)\left(1+n_{t}\right)}-\sigma_{t}+d_{t}-a_{t}+h_{t}
$$

where $b$ and $b^{*}$ are, respectively, net domestic debt and net foreign debt in terms of GDP, $\pi$ is the inflation rate, $n$ is the real GDP rate of growth and $\varepsilon$ is the nominal exchange rate of depreciation.

Equation (5) may be used to simulate the path of the net domestic debt in Brazil over the medium term taking into account specific assumptions about the primary deficit, inflation rate, rate of growth of real GDP, nominal exchange rate devaluation, domestic and foreign interest rates, and seignorage revenues. In addition, since the government intends to continue its privatization programme, one needs to make assumptions about how that programme will be implemented. Finally, it is necessary to take into account the fact that the government has hidden and contingent liabilities which will be recognized in coming years. $^{26}$

To simulate the public debt path in the coming years, we will make use of Monte Carlo simulation. Therefore, in each scenario, instead of assuming a deterministic path for a given exogenous variable, we will make assumptions about their stochastic processes. For the years 2001 and 2002, we will make use 
Table 13. Deterministic variablese paths

\begin{tabular}{lcllll}
\hline Deterministic variables & 2001 & 2002 & 2003 & 2004 & $2005-2012$ \\
\hline Nominal depreciation (RS/USS) & $25.29 \%{ }^{\mathrm{a}}$ & $6.12 \%{ }^{\mathrm{a}}$ & $1.0 \%$ & $1.3 \%$ & $1.3 \%$ \\
Domestic inflation rate (IPCA) & $6.53 \%{ }^{\mathrm{a}}$ & $4.50 \%{ }^{\mathrm{a}}$ & $3.25 \%$ & $3.25 \%$ & $3.25 \%$ \\
Privatization & $1.00 \%$ & $1.00 \%$ & $0.50 \%$ & $0.50 \%$ & $0.50 \%$ \\
Hidden liabilities & $2.50 \%$ & $1.50 \%$ & $1.00 \%$ & $1.00 \%$ & $0.50 \%$ \\
\hline
\end{tabular}

${ }^{\mathrm{a}}$ Market expectation (FOCUS-BCB-23/11/01).

Table 14. Stochastic variables paths

\begin{tabular}{llllr}
\hline Random variables & Distribution & Min & Mean & \multicolumn{1}{l}{ Max } \\
\hline Primary surplus & Truncated lognormal & $0.00 \%$ & $3.00 \%$ & $4.00 \%$ \\
Real GDP growth & Truncated normal & $2.25 \%$ & $4.00 \%$ & $5.75 \%$ \\
Nom. dom. interest rate 2003 & Triangular & $6.00 \%$ & $9.67 \%$ & $13.00 \%$ \\
Nom. dom. interest rate 2012 & Triangular & $6.00 \%$ & $8.01 \%$ & $10.00 \%$ \\
\hline
\end{tabular}

of market expectations information published by the Brazilian Central Bank (www.bcb.gov.br) on November 23, 2001.

We will work with two scenarios. The first scenario-the status quo scenario-basically assumes that the current IMF agreement until the end of 2002 will be strictly followed, and that the fiscal surpluses will be retained in the years after 2002 . That amounts to a primary surplus of $3.4 \%$ of GDP in 2001 , and $3.5 \%$ in 2002. For the period 2003-2012, the primary surpluses are independently drawn from a truncated lognormal distribution with mean $3 \%$. Inflation is assumed equal to the market expectation values, namely 7.4 and $5.59 \%$ for 2001 and 2002, respectively. After that, we assume that the inflation target for 2003, $3.25 \%$, will be repeated until the end of the simulation period. Nominal depreciation is set for 2001-2002 according to market expectations, and, after that is kept constant at $1.25 \%$. The real interest rate is drawn from a triangular distribution whose mean declines monotonically during the simulation period (see Table 2). The nominal interest rate is obtained interacting the inflation with the real interest rate. Real GDP is supposed to grow by $1.7 \%$ and $2.0 \%$ for 2001 and 2002 , according to market expectations. After that, the fall in real interest rates allows for greater real GDP growth. Those rates are drawn from a truncated normal distribution with mean equal to $4 \%$. For 2001 , the interest rate on the external debt is assumed to be equal to $11 \%$, and, after that, is determined by uncovered interest arbitrage, assuming that expected depreciation equals actual depreciation. Seignorage is determined through the assumption of a constant monetary base for 2001 and 2002, and, after that, a constant monetary base as a share of GDP. Privatization revenues were assumed equal to $1 \%$ of GDP for both 2001 and 2002 , and $0.5 \%$ after that. Hidden liabilities were assumed equal to $2.5 \%$ and $1.5 \%$ of GDP for 2001 and 2002 , respectively, and $0.5 \%$ after that. Tables 13 and 14 summarize the assumptions just described. Table 13 explains the deterministic variables evolution, while Table 14 displays the assumptions used to determine the stochastic variables paths.

Given these hypotheses, the simulation of one thousand paths provided the evolution displayed in Figure 7, where the debt/GDP ratio has a hump-shape, declining after 2004. The histogram for the Debt/ GDP ratio in the final year, shown in Figure 8 , has a mean of $49.5 \%$. The simulation $90 \%$ confidence interval is $(42 \%, 58 \%)$. Therefore, a $5 \% \mathrm{~V} @ \mathrm{R}$ would be $58 \%$, meaning that according to our simulations there would be only a $5 \%$ probability of the Debt/GDP ratio being greater than $58 \%$ in 2012 .

The second scenario is constructed so that we may appreciate the effect of the Debt/GDP path of a more lax fiscal stance. We achieve that by decreasing the average fiscal surplus in $1 \%$ of GDP every year after 2002, i.e. from 3 to $2 \%$ of GDP. The results are displayed in Figures 9 and 10. 


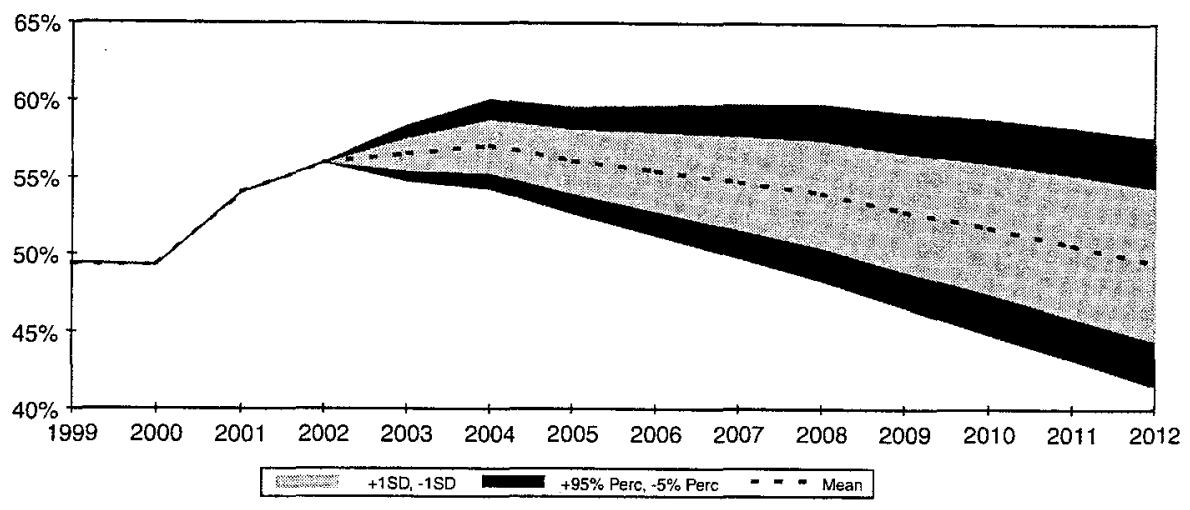

Figure 7. Debt-GDP ratio.

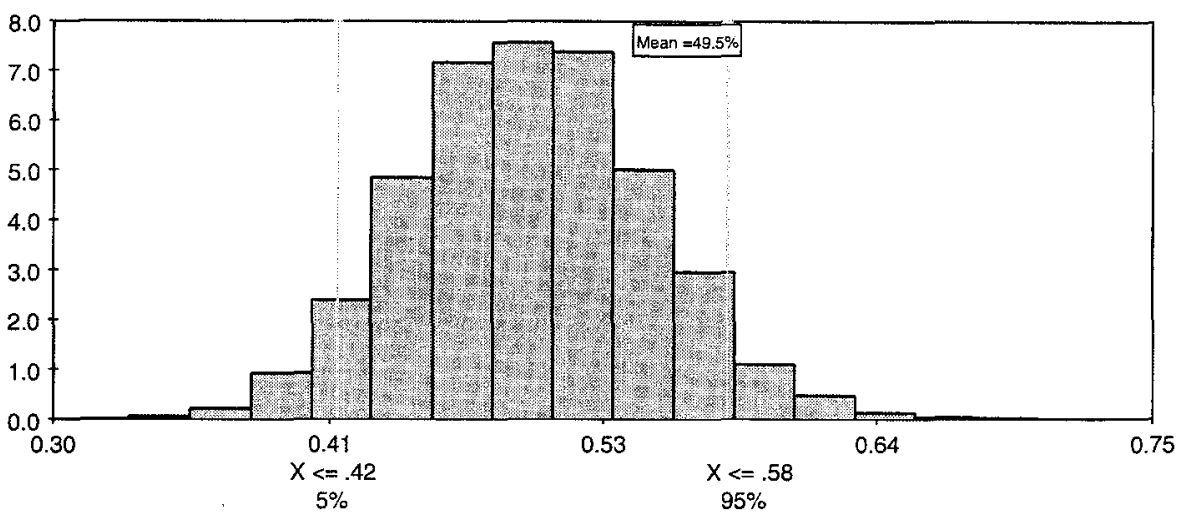

Figure 8. Debt-GDP ratio.

With this slight change in the fiscal stance, the Debt/GDP path loses its hump shape, and exhibits a monotonically increasing trend. The new $90 \%$ confidence interval becomes $(53 \%, 70 \%)$. With such results, it is likely that fears of a default would increase interest rates, making the end result even those displayed here.

Therefore, two conclusions are derived from the simulation results. First, unlike much of the opinions expressed by international banks and a few eminent academics since 1997, the Brazilian Debt/GDP path is not necessarily in an unsustainable path, provided that the current strict fiscal stance remains. Second, unlike many suggestions that claim that the increase in the Debt/GDP ratio was caused only by the high interest rates, and by consequence that a more lax fiscal stance would be possible in the future provided that interest rates were reduced, we have shown that a slight fall in the primary fiscal surplus may put the Debt/ GDP ratio in an unsustainable path.

\section{POLICY DISCUSSION}

As the simulation results from the previous section indicate, even under very favourable macroeconomic conditions the evolution of the net debt to GDP ratio will remain a policy concern in coming years. Under these circumstances, what role should be played by public debt management in the near future? 


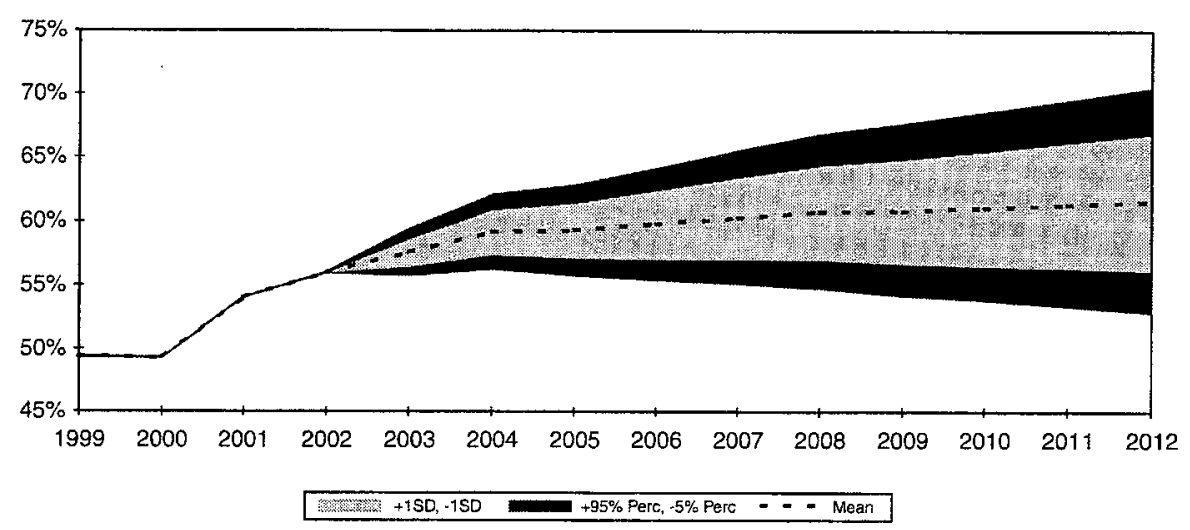

Figure 9. Debt-GDP ratio.

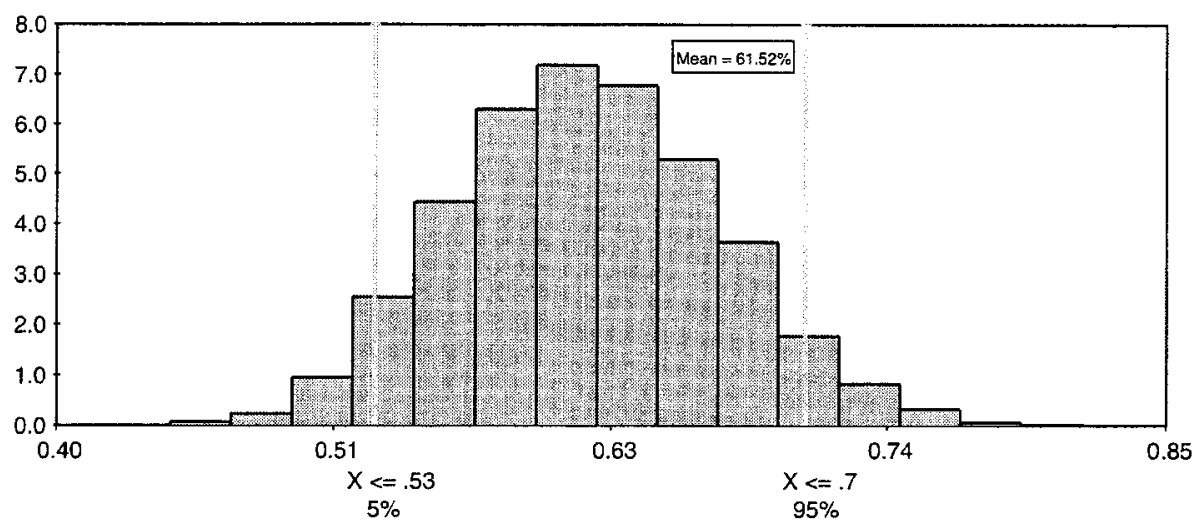

Figure 10. Distribution of net debt in 2012.

We see public debt management as constrained by a fundamental policy consideration in the short run. Although perceptions about the likelihood of a debt rollover crisis in Brazil has improved considerably since the January 1999 devaluation, the large stock of short-term debt remains an important source of anxiety, especially on the part of foreign investors. Even if there are reasons to believe that such a concern is somewhat misplaced, ${ }^{27}$ a practical implication of this fact is that the risk premium on Brazilian securities remains higher than what it would likely be if the same public sector borrowing requirements were financed with longer maturity debt. A central priority of debt management in the short and medium run, therefore, should be to intensify efforts to lengthen the average maturity of the public debt. Furthermore, given the need to reduce the interest burden of the debt and increase the sustainability of the current fiscal stance, such maturity lengthening should naturally be implemented at the lowest possible cost.

What kind of debt instruments will be more appropriate under these conditions? It is expected that under the current IMF-supported programme the share of external and foreign-exchange-indexed debt in the total public debt will be reduced gradually. Therefore, the process of debt maturity lengthening must be conducted through the issuance of domestic debt, either nominal or indexed. 
What should be the relative shares of these instruments in debt placements? For the sake of clarity of the exposition, we partition the question of how much of each kind of debt should be issued in two layers. First, we examine how much nominal against indexed debt should be issued. Second, among the several kinds of indaxed debt, how much of each kind should be issued (zero-duration and inflation-linked). Although the determination of the debt structure is a multiple-choice allocation problem, the two-layered scheme is adequate for the Brazilian case, as we now explain.

To lengthen the average maturity of the debt requires the issuance of indexed debt, since long nominal debt (above two or three years) can only be issued at an abnormally high-risk premium. Therefore, the basic policy recommendation concerning the public debt structure for the Brazilian economy in the coming months is to issue nominal debt with the highest possible maturity without creating an extremely upward-sloping yield curve at the end. For the time nodes previously 'conquered', issue the highest possible amount that do not create 'price-pressure' effects. For the bulk of the rollover and for the new additions to the debt stock, indexed debt should be issued, to lengthen the maturity structure as much as possible.

In terms of placement procedures, the authorities should announce the auctions as far in advance as possible 28 and avoid placing unexpected amounts of short-term securities in order to profit from the low maturity premia of the shorter maturities. Placing short-term debt because it is cheaper in an environment of lack of confidence jeopardizes the situation of the previous long-debt holders, because the short-debt holders have a liquidation option over those, and harms the debt market in the long run. It is akin to the issue of debt seniority: the short-term debt holders hold debt that is senior vis-à-vis the long-term debt holders, since the former will mature before the latter. Information regarding the process of debt lengthening must be well conveyed to the market, so that debt holders know in advance that they will be purchasing liquid instruments, and that the government will not 'cheat' on them by placing shorter instruments in the future.

An important question remains on how much of each kind of indexed debt (zero-duration, inflation-linked, exchange-rate-linked, or another form as discussed below) should be issued. The exchange-rate-linked debt share, as already mentioned, must conform to the guidelines of the current IMF-supported programme. Given the current inflation-targeting framework the use of zero-duration debt poses a version of the well-known time consistency problem. The over reliance on zero-duration debt, as in the current situation with $50 \%$ of total debt in this form, may reduce monetary policy credibility and commitment, because policy makers may become more exposed to choices and trade-offs between tight money policies to contain inflation and the budgetary impact of higher short-term rates. Therefore, it is advisable to reduce the share of this kind of indexed debt in the total public sector debt.

Therefore, the remaining instrument to be used in the process of maturity lengthening is inflation-linked debt. The main objection to this kind of debt indexation is that it may have inflationary effects. Nevertheless, as Price (1997) emphasizes (...) the academic literature suggests no necessary connection between indexed bonds (or indexation in general) and inflation. The emergence of inflation depends on other circumstances and policies that are independent of indexation. Recent government issuers of indexed bonds in fact point to credibility enhancements that may result from issuing indexed bonds, by neutralizing the inflation tax (p. 53). Price's advice is that (..) in newly developing or transition markets, they [indexed bonds] could be envisaged as part of a concomitant package of fiscal and monetary reforms to foster longer-term capital formation, along with strong commitments to price stability (p. 55).

The current share of inflation-linked debt is negligible. This was a result of a policy decision after the Real Plan, when debt managers-convinced that inflation-linked debt was inflationary by conveying to the market a lack of anti-inflationary commitment of the government-decided to phase it out. Our policy advice is to reverse that decision. It is reasonable to assume that there is a natural demand for such longterm-inflation-linked bonds from pension funds, insurance companies, and other market participants whose liabilities both are long-term and display high correlation to the price level. For these market participants, long-term-inflation-linked bonds constitute a hedge, and, therefore, may be sold at a lower yield (higher price). ${ }^{29}$ 
Of course, as the Real Plan achieves its long-term goals of promoting growth in a low-inflation environment, the debt structure should naturally shift towards nominal debt, including long-term securities. However, since it would be infeasible to try to engineer this shift at the present, we see the indexation to inflation as the least harmful way to lengthen the debt maturity.

\section{ACKNOWLEDGEMENTS}

We acknowledge the World Bank's initiative in commissioning and financially supporting this study. All views in the paper are those of the authors. We thank Suman Berry, Clemente del Valle, Xin Zhang, and Eriko Togo for comments and Áureo de Paula, Debora Masullo, Marcelo Rezende, Roberto Cohen and Tatiana Didier, and especially Fernanda Feitosa for superb research assistance. All errors are ours.

\section{NOTES}

1. This section draws heavily on Bevilaqua et al. (1998).

2. Simonsen (1995).

3. For many years the Brazilian Central Bank had a director in charge of Agricultural Development (sic).

4. For a detailed description of the V@R methodology, see Jorion (1955).

5. Adapted from Barcinski (1997).

6. When commenting on the changes in composition, we will often refer to what we think caused those changes (supply-driven or demand-driven changes). Of course, we are aware that we only observe equilibria data, i.e. the intersection between a supply and a demand curve. Therefore, statements such as the ones we offer would actually need careful studies of econometric identification conditions in order to be verified. Nevertheless, we will often take stab on what caused the composition changes: a change in demand, a change in supply, or both.

7. See the previous footnote. In the beginning of the Real Plan the government was fighting several forms of mandatory indexation. It is quite natural to think that courts would be more likely to uphold previous mandatory indexation clauses for wages or other sources of income if the government itself had kept inflation indexation for some of its debt instruments. Apart from this indirect effect, we see no relation between the existence of inflation-linked bonds and inflation (see the policy discussion).

8. A current important policy issue is how much dollar-linked debt (or other kinds of exchange-rate-risk hedges, as future contracts) should the government provide in the current floating exchange rate regime.

9. The bond indexed to the short-run interest rate is a security sold at a discount which had its face-value corrected daily by the average daily interest rates during its term. It is a floating interest rate, adapted to the high frequency required by the high inflation and daily indexation conditions prevalent when it was created (1985). It would be equivalent to a bond whose nominal value is accrued every day by the daily accrual of the Libor. This is the closest one can get to perfect indexation in fixed income markets. It corresponds to a bond of duration zero (that being the reason why we call this type of bond zero-duration bond), since it practically does not suffer any price fall when interest rates go up. These bonds were widely used in times of high uncertainty, as, for example, the crossover to the Cruzado Plan in 1986. On the other hand, monetary policy has a very limited wealth effect, since rises in interest rates do not affect the value of the private financial wealth in these fixed income securities (see Pastore, 1996).

10. These bonds were also of a much longer maturity than the average prevailing at the time, a fact which will also distort the averagematurity statistics for December 1997, as we will analyse in the next section.

11. When talking about debt maturity with foreign economists, we, Brazilian economists, sometimes cause some confusion because of different measures. We use 'months' as the measure, while the former use 'years'. The same used to happen with inflation measures before the Real Plan. We used '\% per month', while everyone else was used to '\% per year'. One hopes that soon we will be able to follow the world convention!

12. Taxa do Banco Central (Central Bank Rate).

13. The argument here follows the lines of the credit rationing model of Stiglitz and Weiss (1981).

14. We asked a Central Bank staff member what had happened in those auctions. He answered that the Central Bank and the Treasury offered longer term bonds, but the bids were all refused, because they were deemed insufficient in quantity, and the yields demanded were both too high and too volatile.

15. Bônus do Banco Central (a nominal bond issued by the Central Bank).

16. Here, we are not determining whether the debt movements resulted from the fiscal, monetary, or exchange rate policy.

17. The total of the uses (in bold in Table 2) is equal to the source variation (in bold in Table 3), both equal to R\$428955. Since this value results from a sum of nominal values in RS during six years, it should be used only as an accounting reference.

18. In Table 3, all figures are in RS, while in Table 4, the figures are in percent of GDP. Therefore, given that nominal GDP grew during the four-year period, the fact that 'other debts' increased in nominal terms, while they decreased as percent of GDP is an indication that the increases occurred more to the end of the period relative to the decreases. 
19. In reality, the relation between privatization and public debt is much complex for at least two reasons. The first is that when a state-owned enterprise is sold, its debts are transferred to the private sector, diminishing the net debt by a value greater than the revenue of the privatization. The second reason is that some state-owned enterprises held public debt as part of their assets. This debt, apparently, was part of the gross debt, but, since it belonged to a state-owned enterprise, was not part of the net debt. After the privatization, it also became part of the net debt. Therefore, the study of the relation between privatization and the public debt is still in progress.

20. Footnote 1 of Table XXI of Nota para Imprensa (Monetary) of Banco Central do Brasil defines the 'Balance Sheet Adjustment' as the following: (basis: Dec/95) Computes the bond issues relative to the Banco do Brasil's recapitalization, the reduction of the investment on the monetary reserve fund due to the court ruling involving the liquidation of the banks Comind and Auxiliar, securitization of debts, the use of "privatization money" in the PND, renegotiation of the Itaipu and Electronorte debts with the SFN, the inclusion of constitution funds, besides the foreign debt difference, due to balance conversions, end of period exchange rates and the flows by the monthly average rate.

21. Thus, it would be expected that the nominal deficit is equal to the net debt variation, for both the states and municipalities as for the state-owned enterprises. Therefore, elucidating these items is still another work in progress.

22. The renegotiation of state's debts by the federal government was a recurrent process in Brazil during the 1990s (see Bevilaquu, 2000).

23. We preferred to present first the nominal values so that the total value to be explained was equal to that published by the Central Bank.

24. See Bevilaqua and Werneck (1998).

25. One can decompose the high domestic interest rate along the lines of the covered interest parity condition, to get: domestic interest rate $=$ foreign interest rate + forward exchange-rate premium + covered interest parity differential (country risk). While the crawling-peg-exchange-rate policy adopted in Brazil after April 1995 created a wedge (the forward exchange-rate premium) that hovered around 10 percentage points, the country risk part had also been substantial. The country risk component was mainly determined by the perception of an unsustainable fiscal policy. Therefore, it is incorrect to say that, had the government abandoned earlier the crawling-peg policy to float the currency, interest rates would have fallen to international levels and the debt problem would have never existed. To make this counterfactual scenario plausible, a much stronger fiscal stance would have been required. And, if that were the case, interest rates would have been much lower even under the crawling-peg regime. After the devaluation, interest payments (in R\$) increased because of the dollar-indexed and the external debt. Also, interest rates did not fall as much as one would like, although the volatility decreased substantially.

26. The social security burden, which is the biggest contingent liability for the public sector, is incorporated in the primary balance.

27. See Bevilaqua and Garcia (1999).

28. This measure was included in the debt management strategy package announced by the Brazilian authorities. According to the newspaper The Economist (11/11/1999), ... among the main features of the central bank's planned reforms are: to hold fewer, bigger auctions of debt, with dates announced further in advance; to reduce drastically the types of bonds on the market (there are currently more than 200, many of them small, illiquid issues relating to former state firms); to allow banks to have "short" positions on the bond market (ie, to sell bonds they do not own), plus other rule-changes to promote liquidity and to be more open in publishing details of the debt.

29. In order to encourage discussion about the best transition strategy toward a higher share of long-term inflation-linked bonds, we propose the following idea. One possible instrument is a bond that would pay the higher of two indices: the inflation index plus a real rate (defined ex ante), or a percentage of the accrual of the daily interest rates (Selic) during the bond's life. In the auction, market participants would bid for the percentage of the accrual of the daily interest rates (the lower the percentage, the more likely to win). This 'mongrel' bond could provide a natural transition between the current zero-duration bonds and the inflation-linked bonds. While the holders of the 'mongrel' bonds would guarantee the natural hedge provided by inflation protection (plus the real rate), they would also retrieve an option to profit from the high interest rates. The gain for the government would be the decrease of the harm in the fiscal accounts posed by an increase in short-term interest rates, thereby alleviating the time consistency problem discussed before. Another similar 'mongrel' bond could be constructed by adding options to a standard inflation-linked bond (plus an ex ante real rate) with maturity of several years. These options, to be exercised at the beginning of each year of the bond's maturity, would change the yield from inflation plus the real rate to a percentage of the accrual of the daily interest rates during the following year. I.e. every year the debt holder would decide ex ante which index would be used to compute the bond's return. As before, the percentage of the accrual of the daily interest rates would be defined in the auction. The expectation is that with the success of the plan, market participants would not exercise the options, thereby in fact migrating to inflation-linked bonds, and alleviating the fiscal, and the derived monetary policy, time consistency problems. Again, the possible benefit of these 'mongrel' bonds would be to allow the maturity lengthening of the debt with the minimum possible fiscal cost and without generating time consistency problems for the inflation-targeting framework.

\section{REFERENCES}

Barcinski A. 1997. Risco de Taxa de Juros e a Divida Pública Federal no Brasil Pós-Real. BNDES, Rio de Janeiro, 85pp. Bevilaqua AS. 2000. State-government bailouts in Brazil. Discussion Paper No. 421, PUC, Departmento de Economia, 52pp.

Bevilaqua AS, Garcia M. 1999. Banks, domestic debt intermediation and confidence crises: the recent Brazilian experience. PUC, Departamento de Economia, Rio de Janeiro.

Bevilaqua AS, Werneck RLF. 1998. The quality of the federal net debt in Brazil. PUC, Departamento de Economia, Rio de Janeiro, Discussion Paper No. 385, 18pp.

Bevilaqua AS, Carneiro DD, Garcia MGP, Werneck RLF. 1998. The structure of the public sector debt in Brazil. Mimeo, Departamento de Economia. 
Jorion P. 1955. Value at Risk: The New Benchmark for Controlling Market Risk. University of California: Irvine, 332pp. Pastore AC. 1996. Por que a política monetária perde eficácia? Revista Brasileira de Economia 50.

Price R. 1997. The Rationale and design of inflation-indexed bonds. Working Paper Series No. 97/12, IMF Washington, DC. Simonsen MH. 1995. 30 Anos de Indexacão. Ed. da Fundação Getúlio Vargas: Rio de Janeiro, 176pp.

Stiglitz J, Weiss A. 1981.Credit rationing in markets with imperfect information. American Economic Review 71: 393-410.

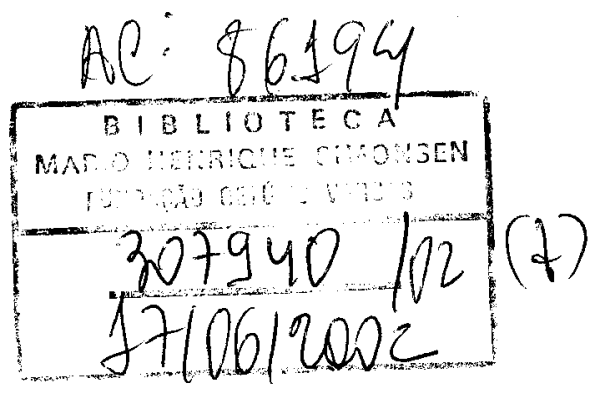

